\title{
PENINGKATAN KEMAMPUAN GURU MATA PELAJARAN SEJARAH DALAM MERENCANAKAN DAN MELAKSANAKAN PEMBELAJARAN MELALUI TEKNIK SUPERVISI KUNJUNGAN KELAS
}

\author{
Slamet Riyadi \\ MAN Rejotangan, J1. Supriyadi Rejotangan Tulungagung.
}

\begin{abstract}
Abstrak: Salah satu sarana untuk meningkatkan kemampuan merencanakan dan melaksanakan pembelajaran adalah melalui teknik supervisi kunjungan kelas. Tujuannya adalah: 1) mengetahui implementasi teknik supervisi kunjungan kelas dalam rangka meningkatkan kemampuan merencanakan dan melaksanakan pembelajaran guru bidang studi Sejarah; 2) mengetahui apakah teknik supervisi kunjungan kelas dapat meningkatkan kemampuan merencanakan dan melaksanakan pembelajaran guru bidang studi Sejarah. Metode yang digunakan ialah rancangan Penelitian Tindakan Sekolah. Kesimpulannya: 1) teknik kunjungan kelas dapat dilaksanakan dengan efektif dan efisien; 2) teknis kunjungan kelas terbukti dapat meningkatkan kemampuan guru dalam menyusun rencana pelaksanaan pembelajaran; 3) teknik kunjungan kelas terbukti dapat meningkatkan kemampuan melaksanakan pembelajaran guru bidang studi sejarah.
\end{abstract}

Kata kunci: kemampuan merencanakan dan melaksanakan pembelajaran, teknik supervisi kunjungan kelas.

\begin{abstract}
Abtract : One means to improve the ability to plan and carry out the engineering supervision of learning is through classroom visits. The purpose of this study are: (1) knowing how the implementation of classroom visits supervision technique in order to improve the ability of teachers of History to plan and implement learning teachers at MAN Rejotangan Tulungagung; (2) determine whether classroom visits supervision technique can improve the ability of teachers of History to plan and implement learning at MAN Rejotangan Tulungagung. The method used is the design of Educational Action Research. The results showed that: (1) the implementation of supervision techniques can be implemented in the classroom visits MAN Rejotangan Tulungagung effectively and efficiently; (2) classroom visits supervision technique proven to increase the ability of teachers in preparing a lesson plan (RPP) as preparation for the implementation of the learning process; (3) technical supervision of classroom visits are proven to increase the ability of teachers to implement learning the history of the MAN Rejotangan Tulungagung.
\end{abstract}

Keyword: the ability to plan and to implement learning, he engineering supervision of learning is through classroom visits.

Permendiknas Nomor 41 Tahun 2007 merupakan salah satu acuan utama bagi satuan pendidikan dalam keseluruhan proses penyelenggaraan pembelajaran mulai dari perencanaan proses pembelajaran, pelaksanaan pembelajaran, penilaian hasil pembelajaran dan pengawasan proses pembelajaran. Permendiknas Nomor 41 ini dimaksudkan dapat meningkatkan mutu lulusan dalam mencapai standar kompetensi lulusan yang pada akhirnya mutu pendidikan semakin baik. Oleh karena itu, proses pembelajaran harus dipersiapkan dengan baik antara lain penyusunan rencana pelaksaan pembelajaran yang biasa disebut RPP dan pelaksanaan pembelajaran yang benarbenar dilaksanakan secara fliksibel dengan 
memanfaatkan seluruh sumber daya yang tersedia baik di dalam sekolah maupun di luar sekolah.

Seorang pakar mengatakan bahwa "Salah satu faktor utama yang sangat menentukan dalam meningkatkan mutu pendidikan adalah guru, guru merupakan titik sentral dalam pembaharuan dan peningkatan mutu pendidikan" (Miarso, 1985). Oleh karena itu, seorang guru harus bisa merencanakan dan melaksanakan pembelajaran untuk meningkatkan kemampuan dirinya melalui teknik supervisi kunjungan kelas.

Perencanaan proses pembelajaran meliputi silabus dan rencana pelaksanaan pembelajaran (RPP) yang memuat identitas mata pelajaran, standar kompetensi (SK), kompetensi dasar (KD), indikator pencapaian kompetensi, tujuan pembelajaran, materi ajar, alokasi waktu, metode pembelajaran, kegiatan pembelajaran, penilaian hasil belajar dan sumber belajar.

Pelaksanaan proses pembelajaran merupakan hal yangpokok dalam mencapai kompetensi yang harus dikuasai oleh masing-masing siswa, bila para guru memiliki kemampuan mengajar yang baik maka proses pembelajaran akan berjalan secara efektif dan efisien. Pembelajaran yang mendidik meliputi: 1) memahami prinsip-prinsip perancangan pembelajaran yang mendidik; 2) mengembangkan komponen-komponen rancangan pembelajaran; 3) menyusun rancangan pembelajaran yang lengkap, baik untuk kegiatan didalam kelas, laboratorium maupun lapangan; 4) melaksanakan pembelajaran yang mendidik di kelas, di laboratorium dan dilapangan dengan memperhatikan standar keamanan yang dipersyaratkan; 5) menggunakan media pembelajaran dan sumber belajar yang relevan dengan karakteristik peserta didik dan mata pelajaran yang diampu untuk mencapai tujuan pembelajaran secara utuh; 6) mengambil keputusan transaksional dalam pembelajaran yang diampu sesuai dengan situasi yang berkembang.

Supervisi merupakan istilah yang sudah lazim dijumpai di lingkungan masyarakat, baik di lingkungan industri, perusahaan, proyek ataupun pendidikan terdapat kegiatan supervisi. Supervisi berasal dari bahasa inggris "Supervision" yang terdiri dari dua perkataan "Super" dan "Vision" . Super berarti atas atau lebih, sedangkan Vision berarti melihatatau meninjau (Nawawi,1984). Supervisi berfungsi membantu (assisting), memberi dorongan (supporting) dan mengajak mengikutsertakan (sharing), (Wiles dalam Sahertian, 2000).

Kunjungan Kelas adalah Kepala sekolah atau supervisor datang ke kelas

untuk melihat cara guru mengajar di kelas, melalui kunjungan kelas supervisor dapat mengobservasi situasi belajar mengajar yang sebenarnnya. Kunjungan kelas bertujuan memperoleh data mengenai keadaan sebenarnya selama guru mengajar, yang berfungsi sebagai alat untuk mendorong guru agar meningkatkan cara mengajar guru dan cara belajar siswa. Paradigma yang dikemukakan oleh Glickman (dalam Bafadal, 2006) untuk memilah-milahguru dalam 4 prototipe guru yaitu:

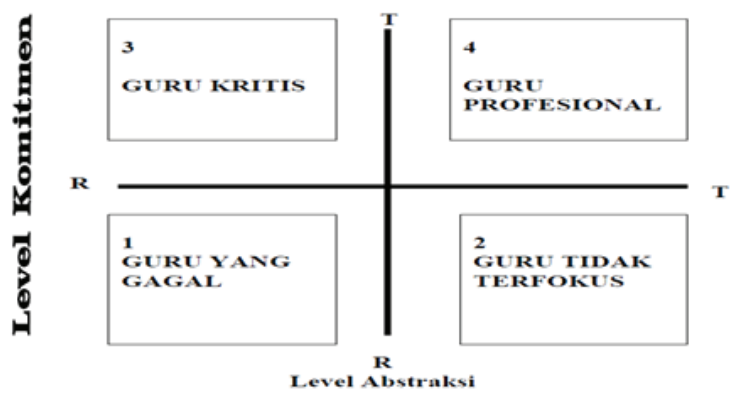

Pertama: Guru-guru yang dikatagorikan sebagai teacher drop outs yaitu

guru ini memiliki komitmen dan kemampuan berfikir abstrak yang rendah. Kedua: Guru-guru yang dikatagorikan sebagai Unfocused worker yaitu guru ini memiliki komitmen tinggi tetapi tingkat kemampuan berfikir abstraknya rendah. Ketiga: Guru-guru yang dikategorikan sebagai Analytical observers yaitu guru ini memiliki kemampuan berfikir abstrak tinggi, tetapi komitmennya rendah. Keempat: Guru-guru yang dikatagorikan sebagai Profesional yaitu guru ini memiliki komitmen dan kemampuan berfikir abstrak yang tinggi.

Berdasarkan pendapat di atas maka penulis tertuju pada obyek guru. Sejauh mana kemampuan guru dalam merencanakan dan melaksanakan pembelajaran? dan upaya apa yang dilakukan oleh kepala sekolah sebagai supervisor dalam rangka meningkatkan kemampuan guru tersebut?. Sementara banyak teknik supervisi dalam rangka meningkatkan profesional guru danpenulis mencoba menggunakan salah satu teknik supervisi yaitu teknik supervisi kunjungan kelas, sehingga permasalahannya dapat 
dijabarkan sebagai berikut: 1) bagaimanakah implementasi teknik supervisi kunjungan kelasdalam rangka meningkatkan kemampuan dalam merencanakan dan melaksanakan pembelajaran guru mata pelajaran sejarah di MAN Rejotangan Tulungagung; dan 2) apakah teknik supervisi kunjungan kelas dapat meningkatkan kemampuan dalam merencanakan dan melaksanakan pembelajaran guru matapelajaran sejarah di MAN Rejotangan Tulungagung.

\section{METODE}

Menurut Nasution (1988) “ desain penelitian adalah suatu rencana tentang cara melakukan penelitian". Penelitian ini menggunakan metode penelitian deskriptif kualitatif, penelitian ini berusaha untuk mengungkap tentang kemampuan merencanakan, melaksanakan pembelajaran dan pelaksanaaan teknik supervisi kunjungan kelas. Menurut para ahli seperti Mc Niff (1988) dan Kemmis dan McTaggart (1988) menyebut satu rangkaian perencanaan, tindakan, observasi dan refleksi itu sebagai siklus (Cycle), refleksi pada siklus pertama akan menentukan apakah siklus pertama itu dicukupkan atau diteruskan ke siklus kedua dan seterusnya.

Penelitian ini memiliki dua variabel yaitu: 1) variabel kemampuan merencanakan dan melaksanakan pembelajaran(Y) dijabarkan dalam penyusunan rencana pelaksanaan pembelajaran (RPP), dan pelaksanaan pembelajaran; 2) variabel pelaksanaan supervisi kunjungan kelas (X) dijabarkan dalam tahap pertemuan awal, tahap observasi mengajar, dan tahap pertemuan balikan.

Penelitian ini berlokasi di MAN Rejotangan Tulungagung, waktu penelitian mulai tanggal 1 September sampai dengan 30 Nopember 2009. Subyek dalam penelitian ini adalah peneliti sendiri sebab peneliti bertindak sebagai Kepala Sekolah MAN Rejotangan Tulungagung. Obyek dalam penelitian ini adalah guru mata pelajaran sejarah dimana mata pelajaran sejarah dipegang oleh guru yang bukan lulusan sejarah.

Penelitian ini menggunakan rancangan Penelitian Tindakan Sekolah yang meliputi: 1) Perencanaan Tindakan; 2) Pelaksanaan Tindakan; 3) Observasi/Pengamatan; 4) Refleksi, dilakukan secara siklus dua sampai tiga siklus.

\section{HASIL}

\section{Siklus Pertama}

\section{Perencanaan}

Pertemuan awal diadakan hari Senin, tanggal 2 Nopember 2009. Materi pertemuan antara lain: 1) rencana RPP diserahkan ke Kepala Madrasah (Peneliti) sekaligus analisis RPP hari Senin, tanggal 9 Nopember 2009; 2) menetapkan kesepakatan bersama antara Kepala Madrasah sebagai supervisor dengan guru mengenai alat penilaian analisis RPP yaitu berpedoman pada alat penilaian yang digunakan dalam sertifikasi yaitu standar penilaian penyusunan RPP; 3) berdasarkan pada pedoman yang telah disepakati bersama maka analisis RPP diperoleh hasil skor 24.

Beberapa temuan dalam penyusunan RPP yang belum sempurna

antara lain: 1) penggunaan apersepsi yang masih belum benar, dan perlu pelurusan yaitu pengertian apersepsi adalah menghubungkan materipembelajaran dengan situasi aktual sehingga siswa tertarik/terfokus pada materi dan selanjutnya tertarik untuk mengikuti penjelasan dari guru; 2) pada langkah-langkah pembelajaran bagian poin B (kegiatan inti) peran guru masih mendominasi, terbukti masih adanya peran guru memimpin pleno kecil; 3) belum ada relevansi antara teknik penilaian dengan bentuk instrumen; 4) pedoman penskoran pada setiap item soal tidak ada.

\section{Pelaksanaan}

Berdasarkan kesepakatan bersama antara Kepala Madrasah sebagai supervisor dengan guru sejarah bahwa pelaksanaan pembelajaran dilakukan pada hari Senin tanggal 16 Nopember 2009 dengan identitas RPP sebagai berikut:

$\begin{array}{ll}\text { Mata Pelajaran } & : \text { Sejarah } \\ \text { Kelas } & : \text { XII / Gasal } \\ \text { Pertemuan ke } & : 1 \\ \text { Alokasi Waktu } & : 3 \times 45 \text { menit }\end{array}$

Standar Kompetensi : 1. Menganalisis Perjuangan Bangsa Indonesia sejak Proklamasi hingga lahirnya Orde Baru. Kompetensi Dasar : 1.3.Menganalisis Perjuangan Bangsa Indonesia dalam mempertahankan kemerdekaan dari 
ancaman disintegrasi bangsa.

Indikator : 1. Mendeskripsikan gejolak sosial di berbagaidaerah pada awal kemerdekaan hingga tahun 1965:
a. DI/TII
b. PKI Madiun 1948;
c. Andi Aziz; d. RMS;
e.PRRI/Permesta.

\section{Observasi}

Implementasi tindakan, peneliti melakukan observasi dengan berpedoman pada alat penilaian kemampuan guru yang biasa digunakan untuk menilai guru yang masuk kuota sertifikasi guru yaitu Penilaian Pelaksanaan Pembelajaran dengan 24 item, yang masingmasingitem skor skor maksimal 5, sehingga skor maksimal memperoleh 120, Adapun hasil penilaian pelaksanaan pembelajaran dapat dilihat padalampiran 7. Selama proses pelaksanaan pembelajaran, hasil yang diperoleh guru Sejarah tersebut ialah 73 .

\section{Refleksi}

Memperhatikan hasil pengamatan dari tindakan yang dilakukan oleh guru dalam proses pembelajaran yang diawali dari hasil temuan awal, perencanaan dan hasil observasi, maka diperoleh hasil skoring yaitu 73; hasil ini selanjutnya diinformasikan kepada guru, selanjutnya diadakan dialog/tukar fikiran mengenai hal tersebut termasuk kekurangan dan kelebihan dengan berlandaskan teori yang ada yaitu Buku "Active Learning" 101 Cara Belajar Siswa Aktif oleh Melvin L. Siberman.

\section{Siklus Kedua}

\section{Perencanaan}

Berdasarkan hasil observasi awal ada beberapa hal yang penting untuk ditindaklanjuti dengan penelitian ini. Pada siklus kedua ini temuan awal yaitu penyusunan RPP belum sempurna. Pada penyusunan RPP masih banyak hal-hal yang belum sesuai dengan pedoman penyusunan RPP sehingga guru memperbaikinya. Hasil RPP yang telah direvisi diberikan skoring berdasarkan pedoman penilaian RPP yaitu 38 .

\section{Pelaksanaan}

Pada tahap ini guru melaksanakan kegiatan pembelajaran tahapyang kedua. Pada tahap ini guru mengacu pada peningkatan kemampuan mengajar yang pada tahap pertama (siklus I) guru mendapatkan hasilskor 73 yang dimungkinkan bisa mendapatkan skor yang lebih tinggi sehingga sampai pada skor maksimal yaitu 120 . Kegiatan pembelajaran pada siklus kedua ini dilaksanakan pada tanggal 23 Nopember 2009.

\section{Observasi}

Pada tahap ini Peneliti (Supervisor) mengamati dengan berpedoman pada alat ukur kemampuan guru yaitu Instrumen Pelaksanaan Pembelajaran (Instrumen yang digunakan untuk Sertifikasi guru ) dengan skor maksimal 120. Berdasarkan pengamatan peneliti (Kepala Sekolah) sebagai supervisor bahwa pada awal pelajaran, guru mengadakan tanya jawab dengan siswa agar supaya semua siswa terfokus pada materi yang disajikan pada hari ini dan guru sudah bisa membedakan antara apersepsi dan motivasi, antara apersepsi dan pre tes; Dalam proses pembelajaran guru sudah bisa memberikan contoh-contoh yang dihubungkan dengan pengetahuan lain yang relevan, termasuk mengaitkan materi dengan realitas kehidupan; pengelolaan kelas sudah cukup baik, termasuk dalam proses pembelajaran sudah mengarah pada pembelajaran kontekstual antara lain berbasis masalah. Pada kegiatan pembelajaran yang kedua ini media pembelajaran dibuat oleh guru bersama siswa dan menghasilkan pesan yang menarik dan pembuatannya secara efisien sehingga partisipasi aktif siswa sangat baik dan guru mau menerima kritikan darisiswa dan akhirnya keceriaan dan antusiasme siswa tumbuh berkembang dengan baik. Pada kegiatan pembelajaran ini penilaian proses dilakukan termasuk tindak lanjut dari penilaian akhir yaitu yang mendapat nilai kurang dari kriteria ketuntasan minimal kompetensi dasar (KKM KD) diadakan remidi dan yang mendapat nilai di atas kriteria ketuntasan minimal kompetensi dasar (KKM KD) diadakan pengayaan. Pada tahap ini peneliti (Kepala Sekolah) sebagai supervisor memberikan penilaian terhadap pelaksanaan proses pembelajaran. Adapun hasil 
penilaian pelaksanaan tahap/siklus kedua ini memperolehskor 108.

\section{Refleksi}

Memperhatikan pengamatan dan tindakan yang dilakukan guru dalam proses pembelajaran maka diperoleh hasil yang cukup baikyaitu 108 . Dengan demikian dapat disimpulkan bahwa guru mampu meningkatkan kemampuan melaksanakan pembelajaran melalui teknik supervisi kunjungan kelas.

\section{PEMBAHASAN}

Pada bagian ini akan dibahas temuan hasil penelitian yang telah dipaparkan pada bagian sebelumnya, baik secara faktual, teoritis maupun implikasi praktis langkah-langkah supervisi kunjungan kelas dalam rangka meningkatkan kemampuan dalam merencanakan dan melaksanakan pembelajaran.

Hasil penelitian ini diperoleh dari tindakan pada siklus I dan siklus II. Hasil penelitian berupa penyusunan Rencana Pelaksanaan Pembelajaran (RPP) pada siklus I mendapatkan skor 24 dan pada hasil penilaian RPP tersebut dapat dibuatkan skala penilaian sebagai berikut:

Skor 1 - 10 : Katagori Kurang

Skor 11 - 20 : Katagori Cukup

Skor 21 - 30 : Katagori Baik

Skor 31 - 40 : Katagori Baik Sekali

Berpijak pada skala di atas maka RPP pada siklus I diperoleh skor 24, dengan demikian RPP pada siklus I termasuk katagori Baik. Pada siklus II RPP telah direvisi dan disempurnakan dan berdasarkan hasil penilaian dokumen RPP maka pada siklus II diperoleh skor 38, dengan demikian RPP pada siklus II termasuk katagori Baik Sekali.

Hasil penelitian yang berupa pelaksanaan proses pembelajaranpada siklus I diperoleh skor 73 dan pada hasil penilaian pelaksanaan pembelajaran dapat dibuatkan skala penilaian sebagai berikut:

$$
\begin{array}{ll}
\text { Skor } 1-30 & : \text { Katagori Kurang } \\
\text { Skor } 31-60 & : \text { Katagori Cukup } \\
\text { Skor } 61-90 & : \text { Katagori Baik } \\
\text { Skor } 91-120: \text { Katagori Baik Sekali }
\end{array}
$$

Berpijak pada skala di atas maka pelaksanaan pembelajaran siklus

I dengan skor 73 termasuk katagori Baik. Sedangkan pada siklus II pelaksanaan pembelajaran mendapatkan skor 108, dengan demikian dapat disimpulkan bahwa pelaksanaan pembelajaran pada siklus II termasuk katagori Baik Sekali. Berdasarkan uraian di atas maka dapat disimpulkan bahwa: (1) teknik supervisi kunjungan kelas dapat dilaksanakan oleh Kepala Sekolah sebagai supervisor sekaligus Peneliti dengan hasil efektif dan efisien; (2) terbukti jika teknik supervisi kunjungan kelas dilaksanakan maka kemampuan merencanakan dan melaksanakan pembelajaran menjadi meningkat dengan bukti adanya perubahan hasil penilaian RPP pada siklus Imendapat skor 24 dengan hasil katagori Baik, meningkat menjadi pada siklusII hasil penilaian RPP mendapat skor 38 dengan katagori Baik Sekali, begitupula pada kegiatan pelaksanaan pembelajaran pada siklus I memperoleh skor73 dengan katagori Baik, menjadi pada siklus II memperoleh skor 108 dengan katagori Baik Sekali. Dengan demikian hipotesis tindakan dapat diterima yaitu jika teknik supervisi kunjungan kelas dilaksanakan maka kemampuan merencanakan dan melaksanakan pembelajaran menjadi meningkat.

\section{SIMPULAN DAN SARAN}

\section{Simpulan}

Pelaksanaan Teknik Supervisi Kunjungan Kelas dapat dilaksanakan di MAN Rejotangan dengan berjalan lancar dan sukses. Melalui Teknik Supervisi Kunjungan Kelas terbukti dapat meningkatkan kemampuan guru dalam menyusun Rencana Pelaksanaan Pembelajaran (RPP) sebagai persiapan pelaksanaan proses pembelajaran. Melalui Teknik Supervisi Kunjungan Kelas terbukti dapat meningkatkan kemampuan guru dalam bidang melaksanakan proses pembelajaran guru mata pelajaran sejarah di MAN Rejotangan.

\section{Saran}

Bertitik tolak dari hasil penelitian ini maka dapat dikemukakan

saran-saran yang kiranya dapat dipertimbangkan saran-saran sebagai berikut: 
1) Guru Mata Pelajaran Sejarah dan Guru Mata Pelajaran lainnya bahwa untuk setiap akan melaksanakan proses pembelajaran hendaknya dipersiapkan dulu rencana pelaksanaan pembelajaran (RPP) sehingga kompetensi yang diharapkan dapat tercapai secara maksimal; 2) Kepala Madrasah selakupeneliti hendaknya selalu memberikan anjuran kepada guru dalam memulai proses pembelajaran hendaknya dipersiapkan dulu rencana pelaksanaan pembelajaran (RPP) agar proses pembelajaran berjalan secara efektif dan efisien; dan 3) Pengawas Pendidikan Agama Islam (PPAI) bahwa teknik supervisi kunjungan kelas ini merupakan alat yang efektif dan ifisien untuk meningkatkan kemampuan guru khususnya kemampuan dalam menyusunrencana pelaksanaan pembelajaran (RPP) dan pelaksanaan pembelajaran.

\section{DAFTAR RUJUKAN}

Bafadal, I. 2006. Peningkatan Profesionalisme Guru Sekolah Dasar. Jakarta: PT Bumi Aksara.

Depdiknas. 2007. Permendiknas No. 41 tahun 2007 Tentang Standar Prosesuntuk Satuan Pendidikan Dasar dan Menengah. Jakarta: Depdiknas.

Kemmis, S. dan Mc.Taggart, R. 1988. The Action Research Planner. Victoria: Deakin University.

Miarso, Y. 1985. Teknologi Komunikasi Pendidikan. Jakarta: CV. Rajawali.

Nasution, S. 1988. Metodologi Penelitian NaturalistikKualitatif. Bandung: Tarsito.

Nawawi, H. 1984. Administrasi Pendidikan. Jakarta: PT. Gunung Agung.

Sahertian, P.A. 2000. Konsep Dasar \& Teknik Supervisi Pendidikan, dalam Rangka Pengembangan Sumber Daya Manusia, Jakarta: PT Rineka Cipta. 